\title{
Tobacco farmers and diversification: opportunities
} and barriers

\author{
David G Altman, Douglas W Levine, George Howard, Hal Hamilton
}

\begin{abstract}
Objective-To assess the knowledge, attitudes, and behaviours of tobacco growers and allotment owners in the southeastern United States.

Design-Cross-sectional telephone survey.
\end{abstract}

Participants-Tobacco growers $(n=529)$ and tobacco allotment owners $(n=417)$ were interviewed by telephone in March 1995.

Setting-Tobacco growing states in the southeastern US.

Main outcome measures-Attitudes of tobacco growers and tobacco allotment owners towards, and experience with, diversification; and attitudes towards an increase in the federal excise tax on tobacco.

Results-Half of the respondents had done something to learn about on-farm alternatives to tobacco, had an interest in trying other on-farm ventures to supplement tobacco income, and found alternatives that were profitable. There was a strong, negative linear trend between age and being interested in or trying alternative enterprises. Structural and economic impediments to diversification were noted by respondents (especially younger respondents), but $73 \%$ supported an increase in the federal excise tax on tobacco if the money was used to help farmers overcome these barriers.

Conclusions-These data suggest that farmers and health professionals have reason to establish dialogue around diversification and using excise tax increases to fund diversification and to promote health. Tobacco companies have been successful in mobilising farmers against tax increases, but efforts must be made to show farmers that tax increases can be beneficial both to their diversification efforts and to public health. The outcome of this dialogue may well affect the economic infrastructure of thousands of rural communities, the livelihood of tens of thousands of tobacco farmers and their families, and the health of millions of tobacco users.

(Tobacco Control 1996;5:192-198)
Keywords: tobacco farmers; tobacco excise tax; diversification

\section{Introduction}

In the US, tobacco use remains the single most产 important risk factor for premature morbidity and mortality. ${ }^{1-3}$ The tobacco industry remains a $\stackrel{\oplus}{-}$ formidable influence in policy circles, in part $\overrightarrow{0}$ because they have raised the concern of $\%$ policy-makers and the public about how tobacco control might negatively impact tobacco farmers and tobacco farming communities. The dependence of individual farmers and local and state $\stackrel{2}{\circ}$ economies on the growing and manufacturing of $\frac{2}{2}$ tobacco is one of the last, and perhaps strongest, $\overrightarrow{\vec{P}}$ of the tobacco industry arguments against tobacco control. ${ }^{4}$ For example, concern about the economic stability of tobacco farmers and tobacco farming communities in the face of tobacco control has been a key obstacle in efforts to raise federal or state excise taxes on tobacco. At the federal level, tobacco farmers and industry lobbyists exert considerable influence. As Bob Geiger, a reporter for the Lexington (Kentucky) Herald-Leader newspaper noted: "The farmers' wrath probably was enough to kill the $\stackrel{3}{3}$ cigarette-tax increase proposed by President $\delta$ Clinton to help pay for his ill-fated health-care reform package." 5 In tobacco-growing states, $ᄋ$ arguments on the importance of tobacco in the local economy are also presented in the context of personal freedom-freedom to farm $\widetilde{N}$ successfully, grow chosen crops, and continue family, community, and cultural traditions. ${ }^{6}$ In 1994, for example, Andrew Schindler, then $\omega$ President and Chief Operating Officer of RJ Reynolds Tobacco Co., told a meeting of farmers: $\stackrel{\circ}{\circ}$ "The anti-tobacco forces want to put us out of $\stackrel{\Phi}{\Phi}$ business and our employees out of jobs".?

What is often lost in these discussions is that the plight of American tobacco farmers is $\mathbb{\Phi}$ affected more by tobacco company practices $\stackrel{\overrightarrow{0}}{\mathbb{2}}$ and worldwide economics than by tobacco control. Over the past 40 years, American tobacco farming has slowly, but consistently, o응 become less profitable. In 1991, the proportion of income the American tobacco farmer derived from the cigarette user's dollar was 3\%, down from $7 \%$ in 1980 and $16 \%$ in 1957 . In contrast, tobacco manufacturers' and wholesalers' share rose by a third between 1980 and 
1991 and by $64 \%$ between 1957 and $1991 .^{8}$ Thus, for every dollar spent on tobacco in 1993, farmers received less than 3 cents and tobacco manufacturers and wholesalers received more than 63 cents. The rest went to excise taxes (29 cents) and retailers ( 5 cents). Due in part to these economic realities and the relatively high price of American tobacco on the world market, tobacco farmers have expanded efforts to diversify because they cannot sustain increasing costs, decreasing profits, and the risk of over-concentration in a crop with an increasingly uncertain future. ${ }^{9}$ Others have stopped growing tobacco altogether. The number of tobacco farms in the United States has dropped substantially: from 512000 in 1954 to 124000 in 1992.

Over the past four decades, tobacco has also lost its centrality to the economy of many tobacco-growing states. The contribution of the tobacco industry to the North Carolina economy, for example, has dropped from $11.3 \%$ in 1960 to $7.8 \%$ in $1993 .{ }^{10}$ With respect to North Carolina farm cash receipts, the contribution of tobacco has dropped from $47 \%$ in 1959 to $19 \%$ in $1993 . .^{11}$ The declining contribution of tobacco is a result of the declining economic competitiveness of American tobacco in the world market, reduced consumption in the United States, and a concerted effort in North Carolina to diversify the underlying economic infrastructure. Livestock and poultry now outproduce tobacco ${ }^{12}$ and cotton is becoming an increasingly popular alternative. $^{13}$

North Carolina is not only first among all states in tobacco production, but also first in sweet potatoes and turkeys; second in pickle cucumbers, poultry, egg products, and trout; and third in hog production. ${ }^{14}$ Hawk Johnson, a long-time tobacco lobbyist, noted, "in 20 years, there won't be any cigarette manufacturing in North Carolina. It'll all be offshore, where it's cheaper and where the markets are." 12

Despite these tobacco company and marketplace influences, tobacco companies continue to identify health professionals and the policies they propose as the primary cause of the problems experienced by American tobacco farmers. Interestingly, there has been little scientific investigation of what tobacco farmers think. For example, farmer perceptions of the economic forces and policy alternatives that could affect their ability to sustain tobacco farming enterprises are unknown. In addition, farmers' attitudes towards and experience with diversification are not well understood. If farmers, elected officials, and the general public believed that diversification was desirable, achievable, and economically advantageous, a key obstacle to the passage of a diverse range of tobacco control policies would be lifted (particularly with respect to excise taxes and clean indoor air). The study reported here is the first study of what a representative sample of southeastern tobacco farmers have done with respect to diversification. We also report data on farmers' attitudes towards increases in tobacco excise taxes.

\section{Methods}

A list of tobacco farmers was bought from a commercial source that compiled remes from several sources: (a) tobacco allotment owners listed on the United States Deptritment of Agriculture's Agricultural Stabilization and Conservation Service (ASCS) recoro from the early 1990s (currently named the Farm Service Agency (FSA)); (b) subscribers to a widely read farm magazine; and (c) marks research surveys of farmers.

This list of tobacco farmers was deawn from a list of individuals who farmed $95 \%$ of the farmland acres in the United States. The list included both allotment owners and allotment renters/operators. This database ois updated continually, a distinct advantage to using the FSA list alone, which is known for being out of date. In brief, the federal allotment system gontrols the amount of tobacco that is grown in'the United States. Farmers can only grow tobæcco if they own or rent allotment; the amount they grow is also set by the allotment system.

A random, stratified sample Tf $_{\text {f }}$ tobacco farmers/allotment owners was obta竎ed. Strata used were acres grown/owned, typ@of tobacco (flue-cured, burley), and state $\vec{\bullet}$ (Georgia, Kentucky, North Carolina, Soutb Carolina, Tennessee, Virginia, other). Each telephone number was dialled three times be and $9 \mathrm{pm}$ (Monday to Saturday) before it was considered a non-response. Interîews lasted approximately 15 minutes and tloe response rate was $72 \%$.

The options potentially available $\hat{\bar{\beta}}_{\text {to }}$ tobacco farmers include ${ }^{15-17}$ : (a) stop growing tobacco and replace it with other on-farm $\mathrm{E}$ nterprises; (b) stop growing tobacco and replace it with off-farm alternatives; (c) reduce the-amount of tobacco grown and substitute it őwith other alternatives, either on-farm or of-farm; (d) maintain the amount of tobacco gewn under allowed allotments and increase sựpplemental agricultural enterprises; and (:) expand current tobacco production an $\overrightarrow{\mathcal{Q}}$. hope to survive as one of the large growers $\delta$

To measure the current an planned activities of tobacco growers, we asked about a wide variety of issues: attempts at diversification, perceptions of barriers to di views on tobacco policy issues, perceptions of the tobacco companies, and views on the health effects of tobacco use. Notâll of these variables are presented in this paper as our focus here is on the farmer's experiences with, and perceptions about, diversifiction. Thus, we present data on whether fagmers were interested in on-farm ventures to supplement tobacco, whether they had ever dowe anything to learn about on-farm alterngtives, and whether any on-farm alternatives they had tried were profitable. We also preşent results pertaining to potential perceived barriers to supplementing tobacco income, in ceived lack of capital, maret outlets, processing plants, off-farm jobs, skills to engage in activities other than tobacco growing. Finally, farmers were asked for their views on an increase in the federal excise tax on tobacco. 

Table 1 Survey responses by population subgroups for diversification outcomes (presented as percentages for categorical variables and odds ratios for
continuous variables)

\begin{tabular}{|c|c|c|c|c|c|c|c|c|}
\hline \multirow[b]{2}{*}{ Question } & \multirow{2}{*}{$\begin{array}{l}\text { Overall } \\
\text { growers } \\
n=529\end{array}$} & \multirow{2}{*}{$\frac{\text { Age }(10 \text { years })^{\ddagger}}{\text { Odds ratio }(95 \% \mathrm{CI})}$} & \multicolumn{2}{|c|}{ Education } & \multicolumn{2}{|l|}{$\begin{array}{l}\text { Tobacco } \\
\text { grown }\end{array}$} & \multirow{2}{*}{$\frac{\text { Dependence }(10 \%)^{\ddagger}}{\text { Odds ratio }(95 \% \mathrm{CI})}$} & \multirow{2}{*}{$\frac{\text { Pounds grown }(10 k)^{\ddagger \S}}{\text { Odds ratio }(95 \% \mathrm{CI})}$} \\
\hline & & & $\begin{array}{l}\leq \mathrm{HS} \\
\mathrm{n}=372\end{array}$ & $\begin{array}{l}>H S \\
n=157\end{array}$ & $\begin{array}{l}\text { Flue } \\
n=231\end{array}$ & $\begin{array}{l}\text { Burley } \\
n=292\end{array}$ & & \\
\hline $\begin{array}{l}\text { In past } 5 \text { years, got job } \\
\text { off-farm to supplement } \\
\text { tobacco income (\% yes) }\end{array}$ & 34 & $0.696^{\star \star}+(0.601-0.806)$ & 34 & & & & & \\
\hline $\begin{array}{l}\text { In past } 5 \text { years, increased } \\
\text { livestock or poultry income } \\
\text { to supplement tobacco }\end{array}$ & & $0.0808 .0001-0.000)$ & 34 & 30 & 28 & $39 \times x$ & $0.875^{\star x}+(0.819-0.936)$ & $0.934^{\star \star} \dagger(0.898-0.971)$ \\
\hline $\begin{array}{l}\text { income (\% yes) } \\
\text { In past } 5 \text { years, increased } \\
\text { non-vegetable crop income } \\
\text { to supplement tobacco }\end{array}$ & 37 & $0.924(0.806-1.060)$ & 35 & 41 & 29 & $43^{\star \star}$ & $0.984(0.924-1.048)$ & $0.973(0.945-1.002)$ \\
\hline $\begin{array}{l}\text { income (\% yes) } \\
\text { In past } 5 \text { years, increased } \\
\text { vegetable income to } \\
\text { supplement tobacco income }\end{array}$ & 26 & $0.788^{\star \star}+(0.677-0.918)$ & 23 & $32^{\star}$ & 33 & $20^{\star \star}$ & $1.064(0.993-1.140)$ & $1.032^{\star}(1.001-1.058)$ \\
\hline $\begin{array}{l}\text { (\% yes) } \\
\text { Ever did anything to learn } \\
\text { about on-farm alternatives }\end{array}$ & 14 & $0.906(0.749-1.095)$ & 14 & 15 & 19 & $10^{\star \star}$ & $0.991(0.909-1.080)$ & $1.025(0.997-1.054)$ \\
\hline $\begin{array}{l}\text { (\% yes) } \\
\text { Has discovered on-farm } \\
\text { alternatives that were }\end{array}$ & 58 & $0.804^{\star \star} f(0.701-0.922)$ & 52 & $71^{\star}+$ & 63 & $54^{\star}$ & $1.050(0.986-1.118)$ & $1.049^{\star \star}(1.016-1.083)$ \\
\hline $\begin{array}{l}\text { profitable (\% yes) } \\
\text { Interested in trying other } \\
\text { on-farm ventures to } \\
\text { supplement tobacco income } \\
\text { (\% interested or very } \\
\text { interested) }\end{array}$ & 53 & $0.824^{\star \star}+(0.720-0.944)$ & 49 & $62^{\star \star} \dagger$ & 57 & 50 & $0.968(0.911-1.028)$ & $1.023(0.997-1.050)$ \\
\hline $\begin{array}{l}\text { interested) } \\
\text { Barrier to supplementation: } \\
\text { nothing as profitable as }\end{array}$ & 51 & $0.725^{\star \star}+(0.631-0.834)$ & 48 & 57 & 54 & $49+$ & $1.018(0.958-1.082)$ & $1.000 \dagger(0.977-1.024)$ \\
\hline $\begin{array}{l}\text { tobacco (\% yes) } \\
\text { Barrier to supplementation: } \\
\text { few processing plants } \\
\text { connecting farmers to } \\
\text { consumers ( } \% \text { yes) }\end{array}$ & 73 & $0.922(0.855-1.151$ & 72 & 75 & 78 & $69^{\star}$ & $1.081^{\star}(1.008-1.160)$ & $1.016(0.985-1.048)$ \\
\hline $\begin{array}{l}\text { consumers (\% yes) } \\
\text { Barrier to supplementation: } \\
\text { lack of capital for new }\end{array}$ & 73 & $0.775^{\star \star}+(0.665-0.903)$ & 73 & 72 & 71 & 75 & $1.027(0.959-1.100)$ & $0.993(0.968-1.019)$ \\
\hline $\begin{array}{l}\text { business ventures (\% yes) } \\
\text { Barrier to supplementation: no } \\
\text { places to sell new products }\end{array}$ & 61 & $0.829^{\star \star}+(0.722-0.951)$ & 62 & 57 & 62 & 60 & $1.073^{\star}+(1.007-1.142)$ & $1.00(0.976-1.024)$ \\
\hline $\begin{array}{l}\text { (\% yes) } \\
\text { Barrier to supplementation: } \\
\text { few low-interest loans or } \\
\text { grants for new business }\end{array}$ & 60 & $0.940(0.821-1.076)$ & 60 & 61 & 58 & 62 & $1.085^{\star}+(1.020-1.156)$ & $1.020(0.993-1.048)$ \\
\hline $\begin{array}{l}\text { ventures (\% yes) } \\
\text { Barrier to supplementation: }\end{array}$ & 58 & $0.763^{\star \star}+(0.664-0.877)$ & 57 & 59 & 60 & 57 & $1.054(0.990-1.123)$ & $1.005(0.981-1.029)$ \\
\hline $\begin{array}{l}\text { lack of off-farm jobs (\% yes) } \\
\text { Barrier to suplementation: } \\
\text { don't have skills to do }\end{array}$ & 51 & $0.924(0.810-1.054)$ & 53 & 46 & 51 & 51 & $1.125^{\star \star}+(1.057-1.198)$ & $1.010(0.986-1.035)$ \\
\hline anything else (\% yes) & 30 & $1.245^{\star \star}(1.073-1.445)$ & 34 & $21^{\star \star} t$ & 29 & 31 & $1.102^{\star \star} \dagger(1.031-1.178)$ & $0.978(0.949-1.009)$ \\
\hline
\end{tabular}

STATISTICAL ANALYSIS

As the dependent variables were all dichotomous (no/yes), the univariate comparisons were either made using contingency table analysis or logistic regression, depending on the nature of the independent variable. Cell percentages are used to summarise the results of the contingency table analysis, along with the results of the corresponding significance test. For the univariate logistic regressions, the results are summarised by presenting odds ratios and the corresponding $95 \%$ confidence intervals. With the exception of the excise tax question, analyses of all outcomes were conducted using only the growers (these questions were asked of growers only because they were not applicable to lessors). All respondents (both growers and lessors) were included in analyses with the tax question as the dependent variable, except when the exogenous variable was either the type or amount of tobacco grown, again because lessors could not respond to these questions.

In addition to the univariate analyses, multiple logistic analyses were conducted. For all multivariate analyses, except those involving the excise tax, the exogenous variables were state of residence (six dummy-coded vectors), age, education (high school graduate or less, versus at least some college education), type of tobacco grown (flue-cured or burley), percentage of income from tobacco, and total pounds grown (in units of $10000 \mathrm{lbs}$ (4.54 tonnes)). When the excise tax was the dependent variable, type and amount of tobacco grown were excluded from the multivariate analysis and a dummy variable, indicating whether the respondent was a grower or a lessor, was included. The fit of the univariate and the multivariate logistic models were assessed using Hosmer and Lemeshow's goodness of fit statistic. $^{18-19}$ 
In past 5 years, got job off-farm to supplement tobacco income (\% yes)

In past 5 years, increased livestock or poultry income to supplement tobacco income (\% yes)

In past 5 years, increased non-vegetable crop income to supplement tobacco income (\% yes)

In past 5 years, increased vegetable income to supplement tobacco income (\% yes)

Ever did anything to learn about on-farm alternatives (\% yes)

Has discovered on-farm alternatives that were profitable (\% yes)

Interested in trying other on-farm ventures to supplement tobacco income (\% interested or very interested)

Barrier to supplementation: nothing as profitable as tobacco (\% yes)

Barrier to supplementation: few processing plants connecting farmers to consumers (\% yes)

Barrier to supplementation: lack of capital for new business ventures (\% yes)

Barrier to supplementation: no places to sell new products (\% yes)

Barrier to supplementation: few low-interest loans or grants for new business ventures (\% yes)

Barrier to supplementation: lack of off-farm jobs (\% yes)

Barrier to suplementation: don't have skills to do anything else (\% yes)

Favour a 5-cent increase in the federal excise tax on tobacco if all of the money came back to tobacco farmers (\% yes)

\begin{tabular}{lll} 
& Age & \\
\hdashline 45 & $45-65$ \\
$(n=126)$ & $(n=274)$ & O
\end{tabular}

$41 \quad 40 \quad 36 \quad 2$

Table 3 Survey responses by population subgroups for support of excise tax increase (presented as percentages for categorical variables and $\overrightarrow{\dot{s}} d s$ ratios for continuous variables)

으

$\begin{array}{lll}\text { Tobacco grown } & \text { Dependence }(10 \%)^{\S} \\ \begin{array}{l}\text { Flue } \\ n=231\end{array} & \begin{array}{l}\text { Burley } \\ n=292\end{array} & \text { Odds ratio }(95 \% \text { CI })\end{array}$

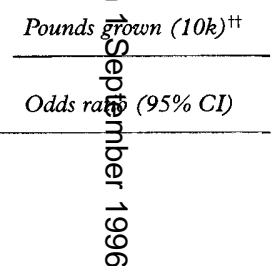

Question

\begin{tabular}{|c|c|c|c|}
\hline & Age $(10 \text { years })^{5}$ & Education & Status \\
\hline Overall $\uparrow$ & Odds ratio $(95 \%$ CI) & $\begin{array}{ll}\leq \mathrm{HS} & >H S \\
\mathrm{n}=372 & n=157\end{array}$ & $\begin{array}{ll}\text { Grower } & \text { Lessor } \\
n=529 & n=417\end{array}$ \\
\hline
\end{tabular}

Favour a 5-cent increase
in the federal excise
tax on tobacco if all of
the money came back
to tobacco farmers
(\% yes)

$\star \mathrm{P} \leq 0.05 ;{ }^{\star \star} \mathrm{P} \leq 0.01$.

† Significance testing of the null hypothesis that the proportion $\pi=0.50$.

$\ddagger \mathrm{P}<0.05$ for the multivariate analyses.

See text below for explanation.

${ }^{+1} 10000$ Pounds $=4.54$ tonnes

\section{Results}

Consistent with farmers in general, most respondents were white $(95 \%)$ and male (82\%). Respondents who grew tobacco $(n=529)$ ranged in age from 25 to 85 years (median $=57$ ). Respondents who were lessors were older than growers $(P<0.001)$ and ranged in age from 25 to 99 years (median $=65$ ). Most respondents reported that their parents $(90 \%)$ or grandparents $(76 \%)$ had also farmed tobacco. A third of growers held a job off-farm. Respondents were active in political activities - a majority had voted $(89 \%)$ or talked to a politician $(51 \%)$ and a substantial minority had written a letter to a politician $(36 \%)$ or contributed money to a politician $(24 \%)$ in the past two years. When respondents were asked whether they smoke cigarettes, or use chewing tobacco, every day, some days, or not at all, 22\% reported smoking cigarettes and $22 \%$ reporting using chewing tobacco "some days" or "every day". Two of three respondents (63\%) thought that "smoking is harmful to people". When asked which constituencies cared about American tobacco farmers, perceived support was higher for tobacco companies (49\%) than for the federal government $(15 \%)$ or public health groups $(1 \%)$.

Tables 1-3 summarise responses to questions about diversification and increasing the federal excise tax on tobacco. Respondents indicated that they had tried to supplement their tobacco income in various ways. In the previous five years, $40 \%$ had attempted at least one supplementation enterprise (got a job off- farm, increased livestock/poultr income, increased vegetable or non-vegetable crop income), $30 \%$ had attempted more than one activity, and only $30 \%$ had nob tried any supplemental enterprise. There was a strong, negative linear trend between ageonand trying alternative enterprises $(P<0.01)$. The average age of respondents who had not tried alternatives was 59.3 , compared wî̀ 50.8 for those who had tried four. Half of had done something to learn about on-farm alternatives to tobacco, had an Ginterest in trying other on-farm ventures to ssupplement tobacco income, and had found -alternatives that were profitable.

On the other hand, a number structural and economic impediments to difersification were noted by respondents - for example, nothing as profitable as tobacou, or few processing plants connecting farmers to consumers. Overcoming barriers of this kind require substantial financial resources. Along these lines, we found that almost three of four respondents (73\%) supported 0 a 5 -cent increase in the federal excise tax of tobacco if the money was used to help farmegs. The univariate and multivariate analy\&s yielded similar results and thus both are क्wncluded in table $1 .^{\star}$ For example, the univarigte analyses

*The Hosmer and Lemeshow goodness fof fit statistic showed that the null hypothesis that the mootel fit the data could not be rejected for 17 of the 18 univariate and all of the multivariate logistic models that yielded statistically significant logistic coefficients. The only univariate model that did not fit was the regression of having an off-farm job on age. 
showed that age was significantly related to having an off-farm job in the past five years, that is, as a farmer gets older, the probability of taking an off-farm job decreases. The odds ratio was 0.696 , indicating that, for a 10 -year increase in age, the predicted odds associated with having an off-farm job decrease by 0.696 times. Alternatively, for every 10-year decreasein age, the odds of having an off-farm job are predicted to be $1.4(1 / 0.696)$ times higher. Similarly, the probability of having an off-farm job is associated $(\mathrm{P}<0.05)$ with type and amount of tobacco grown, and percentage of income from tobacco. For example, these results indicate that for every $10 \%$ increase in total dependence on tobacco, the predicted odds of having an off-farm job decrease by 0.875 , whereas for every $10000 \mathrm{lbs}(4.54$ tonnes) of tobacco grown, the odds of having an off-farm job are expected to decrease by 0.934 .

For the most part, exogenous variables that were statistically significant in univariate analyses were also statistically significant in multivariate analyses. For example, as indicated by the dagger symbol in table 1 , the effect of age on having an off-farm job remained significant after controlling for state of residence, education, type of tobacco grown, percentage of income from tobacco, and total pounds grown $(\mathrm{P}<0.05)$. There are exceptions to this pattern, notably with type of tobacco grown. That type of tobacco grown became generally non-significant in multivariate analyses reflects the confounding of type of tobacco grown with state of residence, that is, type of tobacco grown, which proved significant in univariate analyses, is highly related to state of residence. Virtually no farmers in Kentucky and Tennessee grow flue-cured tobacco, whereas the opposite pattern is evident in South Carolina and Georgia, where virtually no farmers grow burley. There is more diversity in North Carolina and Virginia but, in these states, most farmers produce flue-cured tobacco.

Overall, the results show that age is most consistently associated with the dependent variables (see table 2 for a breakdown of the age effect in three age categories). Dependence upon tobacco income and education also played a role. With respect to age, the odds of being interested in on-farm ventures, learning about on-farm alternatives, discovering profitable alternatives, and increasing nonvegetable crops all increased for younger farmers. On the other hand, younger farmers are also more likely to perceive barriers to diversification, with the exception of not believing that they have the skills to engage in other activities. Perceptions of barriers also increase with dependency on tobacco income.

\section{Discussion}

Concern about the long-term health and economic future of the tobacco farmer has grown substantially in the last few years. ${ }^{20-22}$ Amid a backdrop of declining American tobacco consumption and increasing American tobacco company purchase of foreign-grown tobacco and production facilities, ${ }^{21-23}$ diverse groups such as elected public officials, health응 professionals, and growers have begun $\bigcirc$ exploring together ways to help the American tobacco farmer. We believe that farmer diversi- $\underline{\overrightarrow{0}}$ fication and the subsequent economic development it produces will decrease public and $\stackrel{\vec{S}}{\vec{S}}$ policy-maker resistance to tobacco control.

Data from this study suggest that farmers 들 and health professionals have reason to $\frac{\bar{\rho}}{\partial}$ establish dialogue around diversification and $\stackrel{\mathbb{Q}}{\complement}$ using excise tax increases to fund diversification. Indeed, there were no subgroup $\vec{\circ}$ differences in expressed support of a tobacco excise tax increase (provided that farmers $\vec{\omega}$ received money from this tax), reflecting wide- $\stackrel{\sim}{\overrightarrow{0}}$ spread support of an intervention that will both $\overrightarrow{0}$ help farmers diversify and promote public health. With respect to support of the $\operatorname{tax} \vec{\theta}$ increase, the question posed to respondents proposed a five-cent increase with farmers receiving all of the proceeds. We do not know $\vec{\omega}$ whether respondents would support larger $\operatorname{tax} \frac{\mathbb{D}}{0}$ increases-for example, 50 cents or $\$ 1.00$ - $\frac{\vec{\Phi}}{\mathbb{D}}$ even if they received 5 cents. Most respondents $\frac{3}{8}$ in this study indicated both an interest in and $\frac{\Phi}{2}$ experience with diversification and were $\vec{\varphi}$ supportive of an excise tax increase to help them and their communities.

Historically, tobacco companies and tobacco farmers have worked closely together on tobacco policy. Congressman Scotty Baesler (Democrat from Kentucky) noted that tobacco companies have made opposition to tobacco excise tax increases the key issue for tobacco farmers, even $\frac{0}{3}$ though the level of taxation will have a greater effect on industry income than on farmer income. ${ }^{24}$ This view was echoed by former President Jimmy Carter" : "What tobacco industry executives are not telling these farmers is that a stiff tobacco tax, with a portion earmarked to tobacco-growing regions, would have little effect on tobacco farmers, their communities and their states, and may actually be beneficial ... 훙 Farmers and workers are suffering hard times because tobacco companies are importing more than one-third of the tobacco used in US-made cigarettes, producing more cigarettes overseas and automating production to eliminate manufacturing jobs. While encouraging American farmers to fight tobacco taxes, major tobacco companies are teaching growers in other countries how to produce tobacco for the US market."

Tobacco companies have also organised tobacco farmer opposition to the Food and Drug Administration (FDA) regulations. A lead article in the 11 January 1995 issue of the Lexington Herald-Leader was entitled: "Tobacco industry fights FDA with polls, farmers, smokers". ${ }^{26}$ The article noted that in just two months, 50000 Kentucky farmers signed a petition opposing FDA regulation. In addition, the Flue-Cured Cooperative Stabilization Corporation (representing 180000 growers in five Southern states) and the Eastern Dark Fired Tobacco Growers Association (a Tennessee cooperative for smokeless-tobacco farmers) joined tobacco manufacturers in lawsuits challenging the FDA's proposed rules. ${ }^{27-28}$ 
Although the specific effects of these activities are unclear, they provide evidence that tobacco farmers are willing to exert whatever influence they have on public health policy.

Tobacco industry statements have thus far influenced tobacco farmers and farm organisations to promote a solidarity philosophy. Pro-farmer constituencies, including some state government agencies, have engaged their public relations machines in efforts to promote this philosophy, and have been reasonably successful in influencing how local press cover the issue. The lack of positive reporting about diversification also shapes the general public consciousness, and thus the overall political climate. At a July 1994 speech given at the annual meeting of the North Carolina Flue-Cured Tobacco Cooperative Stabilization Corporation, State Agriculture Commissioner Jim Graham, said: "The [tobacco tax] goal is not to support health care but to destroy a great industry that employees hundreds of thousands, promotes diverse agriculture on the state's small farms and generates an annual tax of $\$ 12$ billion. I'm proud to be a part of such an industry and I'm honored to defend it." 29 As noted in an economic analysis of declining tobacco product sales, the southeastern tobacco states would lose jobs in the absence of tobacco spending but not as many as earlier thought. In addition, this analysis illustrated that all other regions of the country would experience a net gain in employment. ${ }^{4}$

We believe that health professionals must learn to work more closely with tobacco farmers and farm organisations, emphasising their joint interest in diversification. In particular, health professionals and farmers can work together to promote tobacco excise tax increases and allocation of tax revenues to support diversification. To succeed, health professionals must become fluent in the economics of tobacco farming because economic issues are central on the minds of growers and grower organisations. The tobacco industry has been successful in mobilising farmers against such a tax, but efforts must be made to show farmers that this approach is beneficial both to their diversification efforts and to the public health of the nation. It is not an unrealistic possibility that farmers will support such an approach. Our data show that all groups of farmers favour an excise tax increase that benefits them and that younger farmers in particular are already engaged in some diversification efforts and are interested in learning and doing more.

There are, nonetheless, perceived and real barriers to diversification. It may seem paradoxical that younger farmers are both more interested in diversification and perceive more barriers to diversifying. We found, however, that older farmers had made fewer diversification attempts and thus had probably thought less about, and had less actual experience with, the barriers noted by younger farmers. These barriers to diversification are real, but with innovative policies and adequate resources, surmountable. Indeed, the Community Farm Alliance, the Center for Sustainable Systems, the Rural Advancement Foundation International, and other organisa- tions are currently involved in efforts-to explore alternatives for tobacco farmers. ${ }^{3031}$ The challenge, at the level of the individgal farmer, will be to find and develop a fit between the skills and infrastructure capability of toba $\mathrm{e}$ farmers with other farming or business venures. The challenge at the policy level will be to foster farmers' risk-taking by controlling gisk, taking advantage of existing tobacco equipment and organisational infrastructure, and proyiding technical assistance where needed, includang feasibility and market analyses, business plåmning, and evaluation. $^{32}{ }^{33}$ In addition, it is indortant to evaluate the effects of diversification over a period of several years because somesalternative enterprises may be profitable for jæst a short period of time and thus not sustainable. A diverse array of solutions need to be considefe्ed because American tobacco growers are notsa homogenous group. With respect to the size of the tobacco farm, in 1992, for example, 6.7 acres was harvested from the average tobacco farm. ${ }^{34}$ This average reflects the fact that there are both very small growers and very large growers of these growers will obviously be different.

Diversification is ultimately the only strategy that will result in sustainable $\vec{\ominus}$ economic development for small-family fa\%pners. We believe that farmers, farm organisgtions, and health professionals can pursue a poicy agenda that is mutually beneficial. If meanthgful rural economic development can be fostefor through earmarking of tobacco excise taxe this will result in an infusion of resources forming communities and in reduced tobac use. The Rural Advancement Foundation I Ifernational noted the human dimension of this is ${ }^{31}$ : "The handwriting is on the wall ... Our goal should not be to save tobacco, but to save whose livelihoods depend on tobacco." Haß̧Hamilton, then Director of the Community Farm Alliance, said: "There is no single, high-valme crop to replace tobacco, nor a single marketônchannel to be created or subsidised. Instead thejanswer lies in a more complex, yet ultimătely more long-lasting, solution: the devel@pment of agricultural infrastructure so that fărmers can grow, sell, and process a wide Svariety of commodities other than tobacco." Unfess American tobacco becomes more price cornpetitive on the world market (foreign tobacco is ${ }^{2}$ third to a half the cost of American tobacco), the number of American growers will likely declipe and the number attempting alternative enterpprises will increase. In addition, both agricultural and nonagricultural options must be exp red. It is unlikely that adequate economic development can be achieved with agricultural solutions alone.

The study reported here provi data to guide what we hope will be a\$ ongoing dialogue among farmers, farm organisations, and health professionals. The outcome of this dialogue may well affect the o economic infrastructure of thousands of rurafocommunities, the livelihood of tens of the tobacco farmers and their families, and the health of millions of tobacco users.

This study was supported by grant $2 \mathrm{RT} 0227$ from the Robert Wood Johnson Foundation. 
1 US Department of Health and Human Services. Smoking and health, a national status report: a report to Congress, 2 nd ed. Rockville, Maryland: Centers for Disease Control, Office on Smoking and Health, 1990. (DHHS publication No (CDC) 87-8396.)

2 US Department of Health and Human Services. Reducing the health consequences of smoking: 25 years of progress. $A$ report of the Surgeon General, 1989. Rockville, Maryland: Public Health Service, Centers for Disease Control, Office on Smoking and Health, 1989. (DHHS Publication No (CDC) 89-8411.)

3 McGinnis JM, Lee PR. Healthy people 2000 at mid decade. FAMA 1995;273:1 123-9.

4 Warner KE, Fulton GA, Nicolas P, Grimes DR. Employment implications of declining tobacco product sales for the regional economies of the United States. $\mathscr{F} A M A 1996$ 275:1241-6.

5 Geiger B. Tobacco snuffs out legislation industry enjoys friends cultivated in GOP Congress. The State (Columbia, South Carolina) 1995 Mar 26:G1.

6 Brooks JE. Green leaf and gold: tobacco in North Carolina. Raleigh, North Carolina: North Carolina Department of Cultural Resources, 1975.

7 Maddrey P. Winston market marks 126th opening day: Tobacco growers disappointed with opening prices. Winston-Salem (North Carolina) fournal 1994 Aug 3:13.

8 Grise V. Tobacco situation and outlook report. Washington, DC: US Department of Agriculture, Economic Research Service, 1992.

9 Carlton C. Beyond tobacco: With trouble ahead, some Kentucky farmers focus on array of alternatives. Lexington (Kentucky) Herald-Leader 1994 Sep 11:A1

10 O'Connor T. How important is tobacco in North Carolina? North Carolina Med $\mathcal{f}$ 1995;56:28-32.

11 Brown B. Tobacco's contribution to the North Carolina economy. Raleigh, North Carolina: North Carolina Cooperative Extension Service, 1995.

12 Booth W. Up in smoke. Greensboro (North Carolina) News and Record 1994 Jul 3:F1.

13 Greising D. A cotton-picking land rush. Business Week 1994 May 9:57.

14 Guillory F. Attuned politician responds to tobacco's "trouble". Raleigh (North Carolina) News and Observer 1994 May 20.
15 Davis JM, Ferguson JM. New crops for North Carolina. Raleigh, North Carolina: North Carolina Cooperative 응
Extension Service, 1992.

16 Adams F. The tobacco industry in transition. Lexington, Massachusetts: Lexington Books, 1981.

$17 \mathrm{Kahn}$ AS. An economic analysis of the future of tobacco farmers in North Carolina: Viable alternatives for their survival. $\overline{0}$ Greensboro, North Carolina: North Carolina Agricultural and Technical State University, 1988

18 Hosmer DW, Lemeshow S. Applied logistic regression. New York: Wiley, 1989

19 Hosmer DW, Lemeshow S. Goodness of fit tests for the multiple logistic regression model. Communications in Sta- 으 multiple logistic regression model. Communications in Sta- 을

20 Hamilton H. Organizing rural tobacco farmers: Central Kentucky in global context. In: Gaventa J, Smith BE, Will- ® ingham A, eds. Communities in economic crisis: Appalachia and the South. Philadelphia, Pennsylvania: Temple Univer- $\infty$ sity Press, 1990:73-84.

21 Williams B. Brazil: The new tobacco capital. Winston-Salem $\vec{\circ}$ fournal 1995 Apr 17:B1.

22 Anonymous. Cartel: Quotas keep price high-too high for for- $\vec{\omega}$ eign competition. Winston-Salem fournal $1995 \mathrm{Apr} 17 \cdot \mathrm{B} 3$ - क

23 Kilburn PT. All along tobacco road, a way of life is wither- $\vec{\Omega}$ ing. New York Times 1994 Aug 28:Al.

24 Geiger B. Tobacco: a winner in health care reform. Philadel- of phia Inquirer 1994 Aug 19:A2.

25 Carter J. A healthy tobacco tax could help farmers too. $\overrightarrow{0}$ Washington Post 1994 Feb 9:A23.

26 Geiger B. Tobacco industry fights FDA with polls, farmers, 음 smokers. Lexington Herald-Leader 1995 Jan 11:B1.

27 Janofsky $M$. Tobacco growers bemoan Clinton smoking proposal. New York Times 1995; Aug 12:A1 28 Lambert W, Geyelin M. FDA's planned tobacco-ad rules $\mathbb{D}$ spur suits over agency's powers. Wall Street fournal 1995;14 Aug:B6.

29 Anonymous. Tobacco restrictions tamper with freedom, supporters say. Agricultural Review 1994 Jul:1.

30 Anonymous. Dying a natural death. American Medical News 1994 Nov 14:14-17. 31 Bates E. Farmers who are kicking the habit. The Nation of
1995 Feb 13:195-8.

32 Hamilton $\mathrm{H}$. Investing in the farms and communities of America's tobacco regions. Berea, Kentucky: Community Farm Alliance, 1993 .

33 Guillory F. From the ashes of a habit. Raleigh News and Observer 1994 Apr 24.

34 Grise VN. U.S. tobacco farming trends. Tobacco Situation and Outlook 1995;TBS-230:34-7.
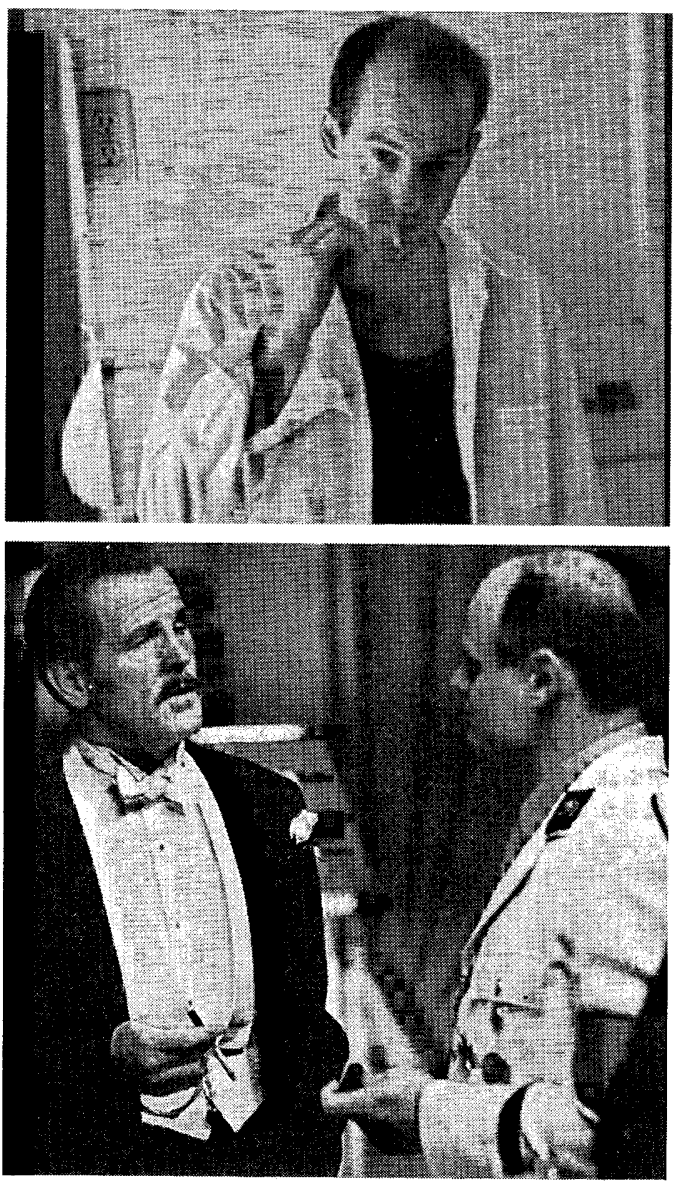

Smokes in the movies. Actor Anthomy Edwards (top), who plays Dick Hickock, "a creepy con man who helps murder an entire family for \$41," in CBS's four-hour remake of In Cold Blood. Edwards is most well-known for playing Dr Mark Greene on the top prime-time TV drama series in the United States-ER. Actor Nick Nolte (bottom), in Mother Night (a Fine Line production), as a Nazi sympathiser in World War II Germany. Source: November 1996 issue of US magazine. 